\title{
Questioning as a Tool to Instill Reasoning Skills among Seventh Grade Students in Science Subject
}

\author{
Sumbal Asghar* \\ Rizwan Akram ${ }^{* *}$
}

\begin{abstract}
Scientific and technological development is crucial for progress and its planning begins in the classroom by teaching Science to nascent minds. Though, teaching mastery in understanding Science is an ongoing challenge and Pakistan is committed to teaching students to excel in their understanding of scientific and technological development. Development of understanding in Science requires the use of reasoning skills which needs to be inculcated among students. The aim of this study is to use the questioning method to develop reasoning skills among seventh-grade students in science subject. The questioning method is a strategy which can encourage students to think and improve their reasoning skills. Two intact groups of seventh-grade students were selected randomly as control and experimental groups. It was a three-month intervention which consisted of three phases. Separate pre-test/post-test was given for each phase of the study. After the intervention, posttest scores of both groups for the three phases of the research were compared. Major findings of the study addressed the efficacy of questioning as instructional pedagogy for the development of reasoning skills in grade 7 students in Science subject.
\end{abstract}

Keywords: Science education, reasoning skills, critical thinking, questioning

\footnotetext{
* Ph.D Scholar, University of the Punjab, Lahore, Email: sumbalasghar12@gmail.com

${ }^{* *}$ Prof., Chairman, Deptt of Science Education, IER, University of the Punjab, Email: drrarpu@gmail.com
} 


\section{Introduction}

Development in science and technology plays an important role in our daily life. Consequently, science education can help to build a secure future for the next generation in Pakistan. Mastery in understanding science is very important to understand the environment around us. It facilitates students to make clear their thoughts, to ask questions, to check their justifications through observation and measurement. Resultantly they can utilize their results to establish a worthy idea. As a result, a review of the science curriculum was conducted by the Ministry of Education, Government of Pakistan in Islamabad. Their objective was to create a National Science Curriculum which would promote science education in Pakistan, keeping up with the necessarily required standards of science education in the $21^{\text {st }}$ century.

Purpose of science education is to make students able to describe and theorize in the everyday world rather than to test situations in classrooms and laboratories (Van Eijck \& Roth, 2010). Although students are very good at gaining factual and conceptual knowledge, however, they are weak at problem-solving and giving reasoned decisions as per results of the international survey on science education (OECD, 2007). The reason behind this disagreement is that students are focused to acquire factual knowledge through product approach whereas principles and process of learning the concepts are ignored. Additionally, the coverage of content to get good grades is more important rather than to understand it which has changed the focus of classroom interaction. Therefore, the connection between daily life examples of different situations and the principles of knowledge involved behind them is missing.

Development of scientific literacy is the main objective of science education in Pakistan. It is emphasized in the General science curriculum to employ students in problem solving, investigation, and to make justification in different circumstances and situations. Students should be involved in the process of science like to predict and formula tea hypothesis, to use logical connections between ideas and to identify errors and mistakes in reasoning. This application of knowledge in unseen situations by the students needs trained teachers to hold a meaningful conversation in the class. National educational policies urge that interactive classrooms are essential for better learning and improved quality of education from early grades of schooling (National Education Policy 1998-2010, 1998; New Education Policy, 2009)."In connection with learning science, scientific facts, theories, and rationalization cannot 
only be understood by personal interaction with phenomena but such knowledge and understanding have to be constructed through dialogue with both teachers and peers" (Stamovlasis, Dimos \& Tsaparlis, 2006).

As a result, teachers are very enthusiastic for their students to understand and apply knowledge in new situations to solve problems, but they focus more on the learning of content rather than the process which can help students to understand the content. This preference of "content coverage" on "learning how to learn" is not letting students get the command of their learning, getting new thoughts by using their mind and how to interconnect these thoughts. There is growing evidence that classroom communication, especially teacher-student conversation is one of the most significant elements to develop understanding and reasoning among students and guide to develop critical thinking (Crespo, 2006).

Our National curriculum for Science also intends to involve students in a conversation of having meaningful questions in the class. According to it, the educator will put some problem and students will generate some questions like "Why....?" "How....?" and "Should....". Moreover, students should use three processes, namely scientific inquiry, problemsolving and decision making to answer "why, how and should" questions respectively. The teacher does not need to make scientists out of every student; rather they are required to engage students in reasoned discourse and to make use of science to obtain knowledge. Afterward, they are expected to use that knowledge to find reason and evidence to solve problems in their everyday life.

That's why teachers have a high responsibility in the class. They need to design such teaching strategies that go well with the needs of students. They must give such learning opportunities and experiences to the students that make sure to achieve the desired learning outcomes in the curriculum. Learning of students is basically how they learn it. Therefore, the teacher has to play the role of facilitator to support the process of learning. He has to employ students in inquiry, problemsolving and decision-making situations in the class to detect, construct and evaluate arguments to solve issues related to science. Unfortunately, teaching and learning of reasoning skills are inadequate in Pakistani schools and efforts towards encouraging reasoning in education are missing in our institutions.

Continuous use of rote learning methods of teaching and lack of involvement of students in class constraint them to use their knowledge in the world around them. The reason might be that teachers are either poorly trained or untrained and hence not stimulating. They focus more on training them to pass the examination in good grades regardless of 
making them think for themselves. Teachers may have poor knowledge of the content and so discourage questions in the class. As per described before, the development of scientific literacy is the main goal of science education and it can be achieved by engaging students in the scientific process. It requires teachers to use such teaching strategies that make students raise questions and build up their own process of thinking to come to the conclusion. It would help to move with the varying views of science as well as the changing views of effective professional development to make real progress in developing science literacy in Pakistan ("Lack of science education," 2017).

On the other hand, traditional method of teaching dominated in the class is usually seen. It is observed that most of the time teacher lectures and students listen or read books or fill out their practice sheets. Knowledge of the subject is to practice and memorize. The connection between learning in school and everyday life is missing. It would not help to achieve the goal of our curriculum. In spite of this, students must be encouraged to develop a critical sense of curiosity. They must have an understanding that science, environment, and society are connected with one another and are not isolated.

There isa number of factors which have affected our system and the teacher is one of them. On the other side, teachers have their own complaints. According to them, unrealistic conditions in schools do not favor quality teaching-learning. They are overburdened due to the lack of teaching staff and are bound to complete the syllabus prior to examination without any question. So they bring down their burden and limit themselves to only read and preach what is written in the books and ignoring the important features of teaching and learning like improvement of different skills and upgrading the knowledge of students success fully (Khalid, 1998). They cannot pay attention to the individual needs of the students.

Lack of teaching-learning aids like blackboards, libraries, laboratories, etc. is another issue. As they are expected to cover courses on schedule, therefore, it is difficult to create a meaningful learning environment in schools in the given conditions (Shah, Ghazi, Irfan Ullah \&Shah, 2014). At the same time supervision creates another problem. In Pakistan, the process of supervision is actually an inspection and supervisors managed to create only a scary environment (Ahmad, Shafiq ur Rehman, Ali, Iqbal, Ali \& Badshah, 2013). It does not help a teacher to create an environment favorable to develop reasoning skills and sharing arguments freely in the class. 
The present study was designed to develop reasoning skills among a cohort of grade 7 students by incorporating the questioning method as instructional pedagogy at the pre-secondary level. The research was conducted with the same setup of school, teachers, and textbooks but the questioning method was used as an instructional pedagogy to develop these skills. For this purpose, the baseline of reasoning skills among students was determined to find the change in reasoning skills of students and use of questioning as instructional pedagogy in the development of these skills in the experimental group. These questions helped to pursue objectives like, to what extent students support their responses with reasons and evidence and how correctly the reasons and evidence are connected to make a decision. Through this research, the answer to this question is to be determined by measuring the size of the change in reasoning skills of the experimental group at subsequent stages. Before moving to the methodology used in this study, it is pertinent to present and deliberate on findings of previous studies in the related field. An understanding of literature will be helpful in understanding the framework for this research.

\section{Literature Review}

A paradigm shift is seen in the approach of teaching, learning, and assessment of many countries. Thinking skills are heavily emphasized. These skills are definitely very important and can play a significant role in developing twenty-first-century skills among students. It is indeed a demand for high levels of thinking, reasoning and collaborating in today's era. It has deep roots in the educational system of many countries but very little is seen in schools and educational institutions in Pakistan in general. National Education Policy (NEP, 2009) and National Professional Standards for Teachers (NPST, 2009) have also clearly accepted the low standard of teacher's professional development and need to reform curriculum and teacher training programs in Punjab and overall in Pakistan.

Science has influenced every aspect of life and has transformed society. So teachers have to pay special attention while teaching. They need to use special teaching methods to invoke reasoning and curiosity among students. Teachers must ask questions that demand thinking and reasoning instead of recalling memory (Nayyar, 2016). One of the indicators of critical thinking is rational thinking or capacity to think in a logical way (Ennis, 1987). The term 'rational' means the use of reasoning 
for problem-solving purposes. Reasoning involves critical evaluation of one's own and other people's beliefs and actions. It includes identifying an argument, evidence provided in support of argument and evaluating the evidence for the conclusion drawn from it. This evidence can be used by the student to support the conclusion. However, this requires the ability to choose and configure reasons to support a conclusion, give an argument in a logical way and communicate efficiently to present the line of reasoning.

The reasoning is identified as one of the five categories of thinking skills by the national curriculum. This is a central and important thinking skill for students where they have to support conclusions with structured reasons and evidence, make reasoned decisions and valid inferences. The reasoning is the ability to infer a conclusion from one or multiple premises which require probing of logical relationships among information (Cojocariu \& Butnaru, 2014). Many research studies have emphasized the role of class talk as one of the many other factors in teaching and learning process to increase student's knowledge and reasoning ability (Wegerif, 1996). Class talks must include probing questions which demand evidence to support assumptions or to reject information and arguments in decision making. It would allow them to understand different unseen situations with reasons.

Griffin et al. (2012) highlight three domains of learning; knowledge, skill, and attitude while explaining reasoning skills. In the knowledge domain, the student is supposed to learn reason well, use logical thinking, assess evidence, solve the problem and communicate the result of a query. In skill domain student must be able to use different types of reasoning and systematic thinking in carrying out the whole process. Whereas, reasoning attitude is giving reasoned judgments and decisions and solve problems throughout the execution of procedures. Good reasoning does not happen in the vacuum. Whenever someone expresses an opinion, he usually has some information on the topic and knows from where to get more information if needed.

Procedural knowledge begins to proceed when a student starts working on a problem and identifies what he/she has to find out. Subsequently, knowledge advances into understanding significantly when a student moves from simple problems to difficult and then to unknown situations. Reasoning becomes the part of the process when someone deals with difficult problem and knowledge of reasoning means that how a student deals with the problem while using his experiences (Mason, Burton, \& Stacey, 2010). Usually, students follow routine methods to solve familiar problems but unfamiliar problems demand 
reconsideration during thinking and carrying out procedures. Thus thinking leads to reason and understanding (Schoenfeld, 2011).

Teachers can use this sequence to guide students from simply knowing a fact, concept or procedure to using these basics to solve more difficult or unfamiliar problems and leads to systematic reasoning or systematic thinking (Mullis et al., 2003; Griffin et al., 2012; BarrosCastro, Midgley, \& Pinzon, 2013). Moon (2008) talked about the different views of thinkers as they worked towards their solution. One of these is 'weighing up': in which students make simple comparisons positive or negative - to solve the problem. One more view is to 'look at the problem from all angles'. Students analyze a problem from as many different viewpoints as they can and then come up with a solution. They look at different perspectives and angles of the situation in order to make the correct decision. Sometimes they take on the roles of the people in the given problem as if they were in the situation.

Another view is 'looking beyond what is there' and this is represented in the engagement of beliefs and ideas during a discussion in the class. Students use these beliefs and ideas to bear on the problem to make their judgments. They go beyond the immediate 'given' of the situation in the problem. Students recognize the influences themselves that bring them to their decisions. They can realize that the set of solution appropriate for a problem in one situation might not be the same in another. It is kind of looking at the context of the situation.

Undoubtedly decisions can be right or wrong but reasoning skills can be used to get the most effective answer to the question. A reason is a cause or motive for something. It is a defense for your actions, thoughts or opinions like what and why you do, say or think. Reasoning skill corresponds to high order thinking (Kenney \& Lindquist, 2000). It is used in the advanced stages of thought or during problem-solving processes (Yildirum, 2000; Umay, 2003).Webster defines reasoning as the ability to think in a comprehensible and logical manner, along with the illustration of assumptions and the conclusions derived from unspecified or known facts (cited in Gunhun, 2014).

The reasoning is very important in education and students may use more than one method of reasoning to solve problems (Malloy, 1999). Their reasoning skills and ability to use different methods of reasoning are associated with the understanding of their concepts and interrelated skills (Lithner, 2000; Briscoe \& Stout, 2001; Gerald, 2002). According to Duval (1998) reasoning helps to extend the domain of knowledge. It is obvious that meaningful education can be given to the students only when the teacher understand their student's thought process (Battista, 
2007). The teacher becomes more familiar with his student by understanding the student's mind in problem-solving (Makina and Wessels, 2009).

\section{Instruction}

Educational psychology has found through research that mental processes and abilities can be developed and improved (Dweck, 1975, 1986; Graham, 1990). Research suggests that intelligence scores have been shown to improve through guided instruction. This improvement is based on social and contextually bound information processes and the design of intelligence instruments is unable to detach natural and inherent information processes. Actually learning, thinking and participation of students in the class and their level of involvement depends on the nature of questions asked by the teacher (Wilen, 1991). So it is important to define question before using it for developing reasoning skills in students. Cotton (2001) gave a comprehensive definition of the question. He suggests that "A question is any sentence, which has an interrogative form or function". Furthermore, he stresses that "in classroom settings, teacher questions are defined as instructional cues or stimuli that convey to students the content elements to be learned and directions for what they are to do it" (Cotton, 2001).

Eldr and Paul (2003) pointed out that questions define tasks and issues whereas an answer puts a full stop in thought. That is the reason that students who are in the habit of asking questions in the classroom learn more and think better than the students who sit quietly and only listen. Elder and Paul (2003) stressed that effective questioning leads to the transformation of the student's thoughts and ideas. As most of the questions asked in the class are of the lower cognitive level so it is a challenge for the teacher to plan carefully higher cognitive level questions (Cotton, 1988). The Socratic questioning technique is very useful to explore ideas held by the students. It can be used by all teachers at all levels to promote independent thinking in their students. These questions seem simple but are deep throughout. They need clarification, to produce assumption based on reason or evidence and to calculate consequences.

Socrates was convinced that disciplined thoughtful questions can make student to look at the information rationally and to find out its validity. This type of questioning can help them to correct their misconceptions and to construct reliable knowledge (Pau \& Elder, 2007). This can be done by asking them to explain why they did these errors to 
identify their misunderstandings (Molefe \& Brodie, 2010). Such as, sometimes learner may use the right method to solve the problem but follow a wrong course of action to find the solution or by finishing reasoning processes before their confirmation or by leaning towards a known explanation outline due to conceptual inadequacy. This is due to faulty reasoning. It should be explored because this investigation can help to understand the student's thought processes (cited in Gurbuz \& Erdem, 2016). Most students face difficulties in problem-solving due to poor reasoning. Hence, students require conceptual understanding and reasoning skills but a baseless and rushed reasoning process from insufficient understanding of the subject is the problem behind this poor reasoning (Mukucha, 2010).

Likewise, Arslan (2007) found in his study that students have lowlevel reasoning skills at the elementary level in school (cited in Tanisli, 2016). Besides, these studies also describe that different methods and techniques can be used to develop reasoning skills but for this, students and teachers must be asking "why?" frequently because it is most important to develop these skills. Paul and Elder (2006) asserted that teacher, student or anyone indeed wants to probe thinking deeply should make use of Socratic questions. These questions can be asked in many ways like to search the general aspects of course material, for brainstorming, to encourage creativity or to focus on a particular problem. This understanding of student's thinking skills can help the teacher to reconsider the methods or strategies employed in the teachinglearning process if needed.

\section{Methodology}

This study was quasi-experimental in nature. The framework for this study was a design in the natural setting of an activity by a teacher for instructional purposes. Intact group pre-test post-test design was used to minimize the threat to validity. The focus of the research was to use questioning based instructions in the classroom to develop reasoning skills. The change in reasoning skills was assessed by comparing the means of pre-test and post-test achievement scores based on the concepts of the unit included in the study. Generally, the study was to identify the nature and characteristics of questions to develop reasoning ability of students to promote higher order learning in Pakistani socio-cultural class environment. 


\section{Participants of the Study}

The population of the study was comprised of all the students studying in grade 7 in public and private schools of Lahore. As school administration did not grant permission to manipulate teaching in the classrooms. As a result, there was no option except for convenient sampling. The selected school had more than two sections of grade 7, therefore the selection of experimental and control groups was randomly carried out. Intact groups were taken as experimental and control group.

The unit "Mixtures" was selected for research from the whole syllabus because the phenomena stated in this unit had several applications in real life. Researcher practiced questioning as instructional pedagogy to the experimental group to teach this unit which was the focus of the research, whereas the control group was taught by the routine teaching method.

\section{Instruments}

\section{Pre-test and Post-test}

Pre-test and post-test were used to measure the change in reasoning skills (achievement) of the students around the concepts included in the particular unit. Subject experts were consulted for the content of the unit with its learning outcomes. The researcher arranged the concept in the unit and then constructed a worksheet according to them. The worksheet was discussed in the forum of experts before data collection. The test contained 6 unseen questions having sequential parts in which every next part of the question was based on the previous part. The items included in the test were based on three types of questions: knowledge, comprehension and application level with reasoning, considering the concept of reasoning skills defined for the research.

Each item was constructed to identify a disciplined thought process, having all constructs in a sequence to get the embedded idea behind these common concepts of daily life. Students participating in the experimental group and control group were given the same test as a pre-test once at the beginning and then at the end of the unit as a post-test to determine the level of intervention. The test was marked by using the following scoring framework. 
Table 1

Factors used as measures of reasoning skills

\begin{tabular}{|c|c|c|}
\hline Factors & Sub factors & Indicators \\
\hline Look for evidence & Sufficiency & Identify evidence \\
\hline \multirow{4}{*}{$\begin{array}{l}\text { Look for proof to } \\
\text { support assumptions } \\
\text { and beliefs }\end{array}$} & Reliability & Describe evidence \\
\hline & Relevance & \multirow[t]{3}{*}{ Relevance of evidence } \\
\hline & Consistency & \\
\hline & Objectivity & \\
\hline \multirow{10}{*}{$\begin{array}{l}\text { Draw conclusions } \\
\text { Make comparative } \\
\text { judgments from data } \\
\text { and able to adjust } \\
\text { opinions when new } \\
\text { facts are found and } \\
\text { reject information } \\
\text { that is incorrect or } \\
\text { irrelevant. }\end{array}$} & Interpretation of data & \multirow{10}{*}{$\begin{array}{l}\text { Integrate the information } \\
\text { Present concrete ideas } \\
\text { Write similarities } \\
\text { Write differences } \\
\text { Categorize the facts } \\
\text { Use the relationship between } \\
\text { phenomena } \\
\text { Give well-reasoned conclusion }\end{array}$} \\
\hline & Combine ideas and & \\
\hline & information in new ways & \\
\hline & Analyze data for accuracy & \\
\hline & Categorization of facts & \\
\hline & Correlate result & \\
\hline & Look for reasons & \\
\hline & Make comparisons & \\
\hline & Communicate effectively & \\
\hline & $\begin{array}{l}\text { Recognize and correct } \\
\text { discrepancies }\end{array}$ & \\
\hline
\end{tabular}

\section{Data Analysis and findings}

Data analysis was carried out by using statistical techniques of mean, standard deviation, percentage, Spearman Correlation coefficient, and ANCOVA. The study was to determine the use of the questioning method to develop reasoning skills and the results of the post-test clearly indicated a remarkable improvement. Students in the experimental group who was exposed to the questioning method showed a significant improvement in their reasoning skills as compared to the control group in spite of covariate in pre-test scores.

\section{Determination of baseline of reasoning skills among seventh- grade students}

The baseline of reasoning skills was determined by the pre-test scores of the students in control and an experimental group that to which extent do they support their responses with reasons and evidence.

\section{Supporting Responses with Reasons}

It is evident from data analysis that the control group improved its score from $30.72 \%(X=22.12, \mathrm{SD}=7.21)$ to $45.19 \%(\mathrm{X}=32.54, \mathrm{SD}=$ 7.48) on "supporting responses with reasons", at the end of research 
study whereas the experimental group improved its score from $26.74 \%$ $(X=19.25, \mathrm{SD}=3.84)$ to $64.29 \%(X=46.29, \mathrm{SD}=11.40)$ at the end of the research study.

\section{Supporting Responses by Evidence}

It is evident from data analysis that the control group improved mean score of "supporting responses by evidence" from $44.32 \%(X=57.62$, $\mathrm{SD}=13.24)$ to $58 \%(\mathrm{X}=75.42, \mathrm{SD}=12.57)$ at the end of research study whereas the experimental group improved its performance from $42.2 \%$ $(X=55.12, \mathrm{SD}=6.24)$ to $71.32 \%(X=92.71, \mathrm{SD}=15.33)$ at the end of the research study.

\section{Relationship of "Supporting Responses with Reasons" and "Supporting Responses by Evidence" (Applied on the percentage of the mean of gain score)}

Table 2

Relationship Among "Supporting Responses with Reasons" and "Supporting Responses by Evidence" for Experimental and Control group

\begin{tabular}{|c|c|c|c|c|c|}
\hline Variable & Group & $\begin{array}{c}\text { Mean } \\
\text { percentage } \\
\text { of Gain } \\
\text { Score }\end{array}$ & SD & $\begin{array}{c}\text { Supporting } \\
\text { responses } \\
\text { with } \\
\text { reasons }\end{array}$ & $\begin{array}{l}\text { Supporting } \\
\text { responses by } \\
\text { evidence }\end{array}$ \\
\hline $\begin{array}{l}\text { Supporting } \\
\text { responses } \\
\text { with reasons }\end{array}$ & Experimental & 50.39 & 12.19 & - & $\begin{array}{l}.974 \\
(.00)\end{array}$ \\
\hline $\begin{array}{l}\text { Supporting } \\
\text { responses by } \\
\text { evidence }\end{array}$ & Experimental & 41.61 & 9.99 & $\begin{array}{l}.974 \\
(.00)\end{array}$ & - \\
\hline $\begin{array}{l}\text { Supporting } \\
\text { responses } \\
\text { with reasons }\end{array}$ & Control & 15.75 & 6.72 & - & $\begin{array}{l}.937 \\
(.00)\end{array}$ \\
\hline $\begin{array}{l}\text { Supporting } \\
\text { responses by } \\
\text { evidence }\end{array}$ & Control & 13.91 & 5.02 & $\begin{array}{l}.937 \\
(.00)\end{array}$ & - \\
\hline
\end{tabular}

Table 2 shows the relationship among the percentage of the mean of gain scores "supporting responses with reasons" and "supporting responses by evidence" for the experimental and control group. It is 
Questioning as a Tool to Instill Reasoning Skills among Seventh Grade Students 151

evident from Table 2 that these factors were strongly and positively correlated with each other for the experimental as well as control group.

\section{Size of change in reasoning skills of the experimental group during the research study (Friedman test \& Wilcoxon test run on the percentage of mean scores)}

Table 3

Pre-test and Post-test Performance of Experimental Group During the Study

\begin{tabular}{lccccccc}
\hline Test Scores & N & Mean & S.D. & $\begin{array}{c}\text { Mean } \\
\text { rank }\end{array}$ & $\begin{array}{c}\text { Chi- } \\
\text { square }\end{array}$ & df & $\begin{array}{c}\text { Asymp. } \\
\text { sig. }\end{array}$ \\
\hline Pre-test (Mixture) & 23 & 34.52 & 6.85 & 3.09 & 99.65 & 5 & .000 \\
Post-test (Mixture) & 23 & 67.48 & 12.68 & 5.09 & & & \\
\hline
\end{tabular}

As shown in table 3, Comparison of repeated measures using Friedman's test was carried out to compare the percentages of pre-test and post-test scores of the experimental group during the research study. There was found to be a significant difference among the percentage mean scores of the experimental group for pre-tests and post-tests $\left(\chi^{2}(2)\right.$ $=99.65, \mathrm{p}=.000)$. Wilcoxon signed rank test as post hoc test was run for pair-wise analysis of pre-test and post-test scores (as shown in tables given below).

Table 4

Pair-wise Analysis of Pre-test/Post-test Scores of Experimental Group for the Study

\begin{tabular}{lcccccccc}
\hline $\begin{array}{l}\text { Scores of } \\
\text { Mixture }\end{array}$ & N & Mean & S.D. & $\begin{array}{c}\text { Mean } \\
\text { Rank }\end{array}$ & $\begin{array}{c}\text { Positive } \\
\text { Ranks }\end{array}$ & $\begin{array}{c}\text { Negative } \\
\text { Ranks }\end{array}$ & $\begin{array}{c}\text { Asymp } \\
\text {. Sig. }\end{array}$ \\
\hline Pre-test & 24 & 34.80 & 6.85 & 12.50 & 24 & & -4.286 & .00 \\
Post-test & 24 & 67.93 & 12.60 & .00 & & 0 & & \\
\hline
\end{tabular}

As shown in table 4, Wilcoxon signed-rank test showed that there was a significant difference between pre-test and post-test performance of the experimental group during the study $(\mathrm{z}=-4.286, \mathrm{p}=.00)$ with higher mean scores on post-test (mean=67.93). 


\section{Size of change in reasoning skills of the control group during the study (Friedman test $\&$ Wilcoxon test run on the percentage of mean scores)}

Table 5

Pre-test and Post-test Performance of Control Group During The Study

\begin{tabular}{lccccccc}
\hline Test Scores & N & Mean & S.D. & $\begin{array}{c}\text { Mean } \\
\text { rank }\end{array}$ & $\begin{array}{c}\text { Chi- } \\
\text { square }\end{array}$ & df & $\begin{array}{c}\text { Asymp. } \\
\text { sig. }\end{array}$ \\
\hline Pre-test of Mixture & 23 & 40.43 & 11.23 & 4.39 & 95.92 & 5 & .000 \\
Post-test of Mixture & 23 & 56.73 & 10.68 & 5.78 & & & \\
\hline
\end{tabular}

As shown in Table 5, a comparison of repeated measures using Friedman's test was carried out to compare the percentages of pre-test and post-test scores of the control group during the research study. There was found to be a significant difference among the percentage scores of the control group for pre-tests and post-tests $\left(\chi^{2}(2)=95.92, p=.000\right)$. Wilcoxon signed rank test as post hoc test was run for pair-wise analysis of pre-test and post-test scores (as shown in tables given below).

Table 6

Pair-wise Analysis of Pre-test/Post-test Scores of Control Group for the Study

\begin{tabular}{lcccccccc}
\hline $\begin{array}{l}\text { Scores of } \\
\text { Mixture }\end{array}$ & N & Mean & S.D. & $\begin{array}{c}\text { Mean } \\
\text { Rank }\end{array}$ & $\begin{array}{c}\text { Positive } \\
\text { Ranks }\end{array}$ & $\begin{array}{c}\text { Negative } \\
\text { Ranks }\end{array}$ & $\begin{array}{c}\text { Asymp. } \\
\text { Sig. }\end{array}$ \\
\hline Pre-test & 24 & 40.88 & 11.20 & 1.00 & 1 & & -4.258 & .000 \\
Post-test & 24 & 56.79 & 10.45 & 13.00 & & 23 & & \\
\hline
\end{tabular}

As shown in table 6, Wilcoxon signed-rank test showed that there was a significant difference between pre-test and post-test performance of control group during the study $(\mathrm{z}=-4.258, \mathrm{p}=.000)$ with higher mean scores on post-test (mean $=56.79)$.

\section{Comparative analysis of reasoning skills between experimental and control groups}

The pre-test scores of control and experimental group were not equivalent so Analysis of Covariance (ANCOVA) was used to compare the reasoning skills of control and experimental group while controlling the pre-test score difference for both groups. 
Before using ANCOVA, it was ensured that key assumptions of ANCOVA were fulfilled: (i) the covariate (i.e., pre-test scores) was measured before the treatment. (ii) the relationship between the dependent variable (i.e., post-test scores) and the covariate (pre-test scores) is linear (straight line) for control and experimental groups (iii) The homogeneity of regression slopes for the covariate and the treatment was assessed statistically

\section{Comparative analysis of experimental and control group for change in skill "to look for evidence".}

Table 7

Descriptive Statistics for Post-test Scores on "Look for Evidence" by Group

\begin{tabular}{lcccc}
\hline Type of group & \multicolumn{4}{c}{ Post-test } \\
\cline { 2 - 5 } & $\begin{array}{c}\text { Observed } \\
\text { Mean }\end{array}$ & $\begin{array}{c}\text { Adjusted } \\
\text { Mean }\end{array}$ & SD & $\mathrm{N}$ \\
\hline Control & 248.96 & 226.64 & 50.15 & 24 \\
Experimental & 382.20 & 404.53 & 69 & 24 \\
\hline
\end{tabular}

A one-way (ANCOVA) between-group was conducted to compare the post-test scores of control and experimental group on "look for evidence". A significant difference was found between the two groups on post-test scores on "look for evidence" $[\mathrm{F}(1,45)=137.99, \mathrm{p}=.000$, partial eta squared $=.754]$ controlling for pre-test score on "look for evidence".

Table 8

ANCOVA Results for Post-test Scores on "Look for Evidence" by Group and Pre-test Scores

\begin{tabular}{lcccccc}
\hline Source & $\begin{array}{c}\text { Type III } \\
\text { sum of } \\
\text { squares }\end{array}$ & $d f$ & $\begin{array}{c}\text { Mean } \\
\text { square }\end{array}$ & F & Sig. & $\begin{array}{c}\text { Partial } \\
\text { Eta } \\
\text { Squared }\end{array}$ \\
\hline Group & 286901.33 & 1 & 286901.33 & 137.99 & .000 & .754 \\
Look forevidence_pre & 73899.65 & 1 & 73899.65 & 35.546 & .000 & .441 \\
Error & 93555.27 & 45 & 2079.006 & & & \\
\hline
\end{tabular}

Note: $\mathrm{R}^{2}=.754$, Adj. $\mathrm{R}^{2}=.743$, Adjustments made on Look for evidence pre-test mean $=162.73$. Homogeneity of regression tested and not significant: $\vec{F}=1.391$, $\mathrm{p}>$.05. Look for evidence_pre-test regression coefficient $=1.482$ 
There was a strong relationship between pre-intervention and postintervention scores on "look for evidence" by a partial eta squared of .441.

\section{Comparative analysis of the experimental and control group for change in skill "draw conclusion"}

Table 9

Descriptive Statistics for Post-test Scores on "Draw Conclusion" by Group

\begin{tabular}{lcccc}
\hline \multirow{2}{*}{ Type of group } & \multicolumn{4}{c}{ Post-test } \\
\cline { 2 - 5 } & $\begin{array}{c}\text { Observed } \\
\text { Mean }\end{array}$ & $\begin{array}{c}\text { Adjusted } \\
\text { Mean }\end{array}$ & SD & $\mathrm{N}$ \\
\hline Control & 316.48 & 271.96 & 99.09 & 23 \\
Experimental & 566.65 & 611.17 & 131.78 & 23 \\
\hline
\end{tabular}

Table 10

ANCOVA Results for Post-test Scores on " Draw Conclusion" by Group and Pre-test Scores

\begin{tabular}{lcccccc}
\hline Source & $\begin{array}{c}\text { Type III } \\
\text { sum of } \\
\text { squares }\end{array}$ & $d f$ & $\begin{array}{c}\text { Mean } \\
\text { square }\end{array}$ & F & Sig. & $\begin{array}{c}\text { Partial } \\
\text { Eta } \\
\text { Squared }\end{array}$ \\
\hline Group & 977392.87 & 1 & 977392.87 & 123.7 & .000 & .742 \\
ecision making pre- test & 257648.74 & 1 & 257648.74 & 32.55 & .000 & .431 \\
Error & 340400.22 & 43 & 7916.28 & & & \\
\hline
\end{tabular}

Note: $\mathrm{R}^{2}=.742$, Adj. $\mathrm{R}^{2}=.730$, Adjustments made on Draw conclusion pre-test mean=144.37. Homogeneity of regression tested and not significant: $F=.935$, $\mathrm{p}>$.05. Draw conclusion pre-test regression coefficient $=1.41$

A one-way (ANCOVA) between-group was conducted to compare the post-test scores of control and experimental group on "draw conclusion". A significant difference was found between the two groups on post-test scores on "draw a conclusion" [F=123.7, $\mathrm{p}=.000$, partial eta squared $=.742]$ controlling for pretest scores on "draw conclusion". There was a strong relationship between pre-intervention and postintervention scores on "draw conclusion" by a partial eta squared of .431 .

\section{Conclusion and Discussion}

Pre-test scores and a strong positive relationship among these skills in the control group shows that these skills are naturally present in 
students irrespective of the teaching method used. Besides the gain in post-test scores of the control group revealed that these skills were also developed in the control group despite the fact that they were taught by the routine teaching method. Although the difference in pre-test and post-test scores of the control group is very small as compared to the experimental group but still it exists. It shows that these skills develop with the passage of time without the guidance of the teacher. Whatever the teaching method is used students are in the habit of thinking to find the reason but they lack the ability to asses and improve it. They cannot demonstrate these skills properly.

Actually, it is human nature to think and to make decisions but the problem is to be objective. Same is the case with students. Their dilemma in getting objectivity is to discard the evidence that does not support the conclusion that they want to be true because they knew it as such. It is not disbelieving anything. It is about the evaluation of claims on the basis of knowledge they had, which can be prejudiced, unclear, partial and uninformed. They do not view another perspective of the issue. They know that there are flaws but are unable to identify them.

Therefore, an ability which is inbuilt in nature can be further nurtured if it is taken care of. That is why the posttest scores of the experimental group for reasoning and providing evidence skills were higher than those of the control group due to intervention at the end of the research study. As a result, it can be concluded that questioning as an instructional pedagogy has a positive effect on the development of reasoning skills of seventh-grade students for the subject of General Science. Therefore the teacher can use a questioning method or any other similar teaching strategy to develop these skills. Students are already inquisitive about their surroundings and environment. They have the ability to think, reason and make decisions and the teacher is supposed to train them to use these skills.

The post-test scores of the experimental group on four constructs of thinking skills were improved as compared to its pre-test scores; the same pattern was observed for the control group. However, the improvement of post-test scores for the experimental group was higher than that of the control group on reasoning skills. Keeping in view the improved performance of the control group through traditional instruction, it can be deduced that the post-test scores of the control group may be improved due to familiarity and interaction with content. Because the pre and post-tests for assessing critical thinking skills were constructed using the content of the unit and the content was not previously taught to students, we can say that familiarity with the content 
affected their performance on post-test for that unit. On the other hand, the experimental group shows greater improvement than the control group for the same content but with a different instructional pedagogy.

It means that though control group was better in using these skills than the experimental group in pre-test scores and improved in post-test after getting familiar with the content experimental group shows a remarkable improvement in posttest scores due to intervention. Therefore, it can be concluded that a proper reinforcement according to the nature of the content and carefully designed questions or similar teaching strategy can speed up the development of the thinking process. Content along with argument and questions in class discourse can help students to grasp the depth of the content. The teacher just has to teach students the process of thinking. He should help them to employ the logical process of thinking to use reasons to get evidence to derive a conclusion. 


\section{References}

Ahmad, I., Shafiq ur Rehman., Ali, S., Iqbal, S., Ali, F., Badshah, R. (2013). Problems of government secondary school system in Pakistan: Critical analysis of literature and finding a way forward. International Journal of Academic Research in Business and School Sciences. 3(2), 85-96.

Barros-Castro, R. a., Midgley, G., \& Pinzón, L. (2013). Systemic Intervention for Computer- Supported Collaborative Learning. System Research and Behavioral Science, 32(1), 86-105.

Battista, MT.(2007). The development of geometric and spatial thinking. In F. Lester (Ed.),Second Handbook of Research on Mathematics Teaching and Learning. Reston, VA: National Council of Teachers of Mathematics.

Briscoe, C.\& Stout, D.(2001). Prospective Elementary Teachers' Use of Mathematical Reasoning in Solving a Lever Mechanics Problem.School Science and Mathematics, 101(5), 228-235.

Cojocariu, Venera-Mihaela. \& Batnaru, Carmen-Elena. (2014). Asking questions - critical thinking tools. Social and Behavioral Sciences,128, 22-28.

Cotton, K. (1988). Classroom questioning. Retrieved from School Improvement Research Series:

http://people.usm.maine.edu/tcrabtree/MTL_ONLINE/Readings_627 files/04-NWREL.html on 16-09-18

Cotton, K. (2001). Classroom questioning. North West Regional Educational Laboratory.

Crespo, S. (2006). Elementary teacher talk in Mathematics Study Groups. Educational Studies in Mathematics, 63(1), 29-56.

Duval, R.(1998). Geometry from a cognitive point of view. In C. Mammana \& V. Villani (Eds).Perspectives on the Teaching of Geometry for the 21st Century: An ICMI Study. Dordrecht: Kluwer.

Dweck, C. S. (1975). The role of expectations and attributions in the alleviation of learned helplessness. Journal of Personality and Social Psychology, 31, 674-685.

Dweck, C. S. (1986). Motivational processes affecting learning. American Psychologist, 41, 1041-1048. 
Ennis, R. H. (1987). A taxonomy of critical thinking dispositions and abilities. In J. Baron \& R. Sternberg (Eds.), Teaching Thinking Skills: Theory and Practice (pp. 9-26). NY: W. H. Freeman.

Elder, L., \& Paul, R. (2002). The miniature guide to the art of asking essential questions. Santa Rosa, CA: Foundation for Critical Thinking.

Paul, R. Elder, L. (2007). The thinker's guide to the art of Socratic questioning. Santa Rosa, CA: Foundation for Critical Thinking.

Gerald, L. M. Jr.(2002). An evolutionary theory of knowledge and conceptual evolution in science. Global Bioethics, 15(3), 73-80.

Graham, S. (1990). Communicating low ability in the classroom: Bad things good teachers sometimes do. In S. Graham \& V. Folkes (Eds.), Attribution theory: Applications to achievement, mental health and interpersonal conflict (pp.17-36).NJ: Lawrence Erlbaum.

Griffin, P., McGaw, B., \& Care, E. (2012). Assessment and Teaching of 21st Century Skills. London: Springer.

Gunhun, B. C. (2014). A case study on the investigation of reasoning skills in geometry. South African Journal of Education, 34(2).

Gurbuz, R. \& Erdem, E. (2016). Relationship between mental computation and mathematical reasoning. Cogent Education, 3(1).

Kenney, P. A.\& Lindquist, M. M.(2000). Students' performance on thematically related NAEP tasks. In E. A. Silver \& P. A. Kenney (Eds), Results from the seventh mathematics assessment of the National Assessment of Educational Progress. VA: NCTM.

Khalid, T. (1998). Education: An introduction to educational philosophy and history. National Book Foundation, Islamabad, Pakistan pp. 22.35

Lack of science education hindering technological advancements. (2017, December 23). The Express Tribune. Retrieved from (https://tribune.com.pk/story/1590762/1-lack-science-educationhindering-technological-advancements/).

Lithner, J.(2000). Mathematical reasoning in task solving. Educational Studies in Mathematics, 41(2), 165-190. 
Makina, A.\& Wessels, D.(2009). The role of visualization in data handling in Grade 9 within a problem-centered context. Retrieved from http://scholar.sun.ac.za/handle/10019.1/19525 on 08-09-18.

Malloy, C. E.(1999). Developing mathematical reasoning in the middle grades: recognizing diversity. In L.V. Stiff \& F. R. Curcio (Eds),Developing mathematical reasoning in Grades K-12.VA: National Council of Teachers of Mathematics.

Mason, J., Burton, L., \&Stacey, K. (2010). Thinking Mathematically. England: Pearson.

Ministry of Education (1998). National Education Policy 1998-2010. Islamabad; Government of Pakistan.

Ministry of Education (2009). National Education Policy 2009. Islamabad: Government of Pakistan.

Molefe, N. \& Brodie, K. (2010). Teaching mathematics in the context of curriculum change. Pythagoras,71, 3-12.

Moon, J. (2008). Critical Thinking: An exploration of theory and practice. NY: Routledge.

Mukucha, J. (2010). Mathematical reasoning in BODMAS. In Proceedings of the $16^{\text {th }}$ Annual Congress of the Association for Mathematics Education of South Africa (AMESA). Durban: KwaZulu-Natal.

Mullis, I. V. S., Martin, M. O., Smith, T. A., Garden, R. a., Gregory, K. D., Gonzalez, E. J., O’Connor, K. M. (2003). TIMSS - Assessment Frameworks and Specifications 2003. International Study Center (2nd Ed.). Boston, MA: International Study Center.

Nayyar, A. H. (March 04, 2016). Science Education in Schools. Dawn. Retrieved from https://www.dawn.com/news/1243391 on 06-09-18.

NPST: National Professional Standards for Teachers in Pakistan (2009). Retrieved fromhttp://unesco.org.pk/education/documents/step/National $\% 20$ Professional $\% 20$ Standards $\% 20$ for $\% 20$ Teachers $\% 20$ in $\% 20$ Pakistan .pdf.

OECD (2007). PISA2006 Science Competencies for Tomorrow's World. Paris: OECD. 
Schoenfeld, A. H. (2011). How we think. A theory of goal-oriented decision making and its educational applications. NY: Routledge. Retrieved from https://books.google.com.pk/books?id=lwfGBQAAQBAJ\&printsec=fro ntcover\&source $=$ gbs_book_other_versions $\# \mathrm{v}=$ onepage\&q\&f$=$ false

Shah, S. F., Ghazi, S. R., Irfan Ullah., Shah. R. (2014). Problems Faced by Female Teachers at Primary Level in Khyber Pakhtunkhwa Pakistan. International Journal of Elementary Education, 3(2), 34-40.

Stamovalasis, D., Dimos, A. and Tsaparlis, G. ( 2006). A study of group interaction processes in learning lower secondary Physics. Journal of Research in Science Teaching, 43(6), pp. 556-576.

Tanisli, D. (2016). How do students prove their learning and teachers their teaching? Do teachers make a difference? Eurasian Journal of Educational Research, 66, 47- 70.

Umay, A. (2003). Mathematical reasoning ability. Hacettepe University Journal of Education, 28, 188-195.

Van Eijck, M. \& Roth, W. M. (2010). Theorizing scientific literacy in the world. Educational Research Review,5(2), 184-194.

Wegerif, R. (1996). Using computers to help coach exploratory talk across the curriculum. Computers Education, 26(1-3), 51-60.

Wilen, W. W. (1991). Questioning skills for teachers. (3rd ed.). DC: National Education Association.

Yildirim, S. (2000). Effects of an Educational Computing Course on Preservice and in-service Teachers: A Discussion and Analysis of Attitudes and Use. Journal of Research on Computing in Education, 32(4), 479-495.

\section{Citation of this Article:}

Asghar, S., \&Akram, R. (2019). Questioning as a tool to instill reasoning skills among seventh grade students in Science subject.

Pakistan Journal of Education, 36(1), 139-160. 